
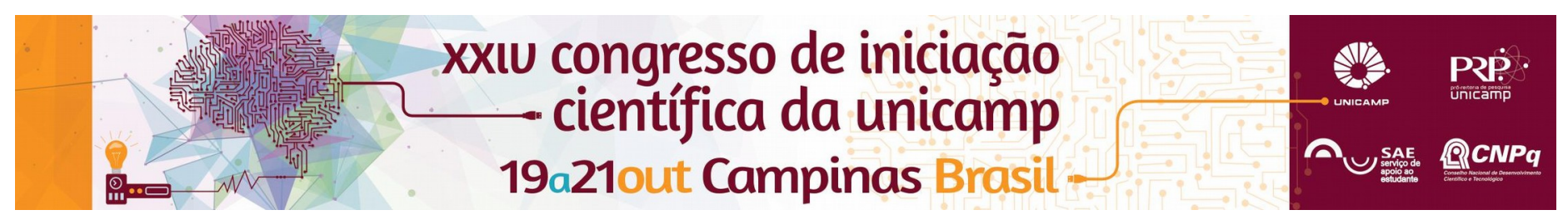

\title{
Funk e a ostentação feminina: Relações de poder produzida pelas personagens femininas na trama dos discursos fílmicos dos videoclipes do Funk Ostentação.
}

\section{Beatriz Marques da Silva*}

\section{Resumo}

O presente trabalho tem por objetivo a investigação da (des)construção das personagens mulheres dentro do funk ostentação, através das narrativas fílmicas dos videoclipes produzidos pela KondZilla, produtora e gravadora de Konrad Dantas, diretor de cinema, vídeo e atualmente considerado o criador da estética de funk ostentação.

\section{Palavras-chave: \\ Funk Ostentação, feminismos, Educação.}

\section{Introdução}

O tema deste trabalho é analisar os discursos fílmicos produzidos pelas mulheres no funk ostentação, com maior foco nos videoclipes dirigidos pela produtora KondZilla. Partindo da ideia de que conhecer é representar ou reconhecer a realidade (Barros, Kastrup 2009), pretendemos conhecer esse fenômeno musical denominado funk ostentação, uma das correntes do movimento musical de funk, para que possamos melhor compreender as complexas redes culturais que estão postas dentro do movimento musical funk e quais são os papéis sociais que estão sendo desenvolvidos para o gênero feminino.

\section{Resultados e Discussão}

Utilizamos como método para a realização dessa pesquisa, o método cartográfico, que consiste em acompanhar os percursos que o objeto de pesquisa tem tomado, as implicações no processo de produção, conexão de redes ou rizomas. Para estar de acordo com o método proposto, fizemos um levantamento da historicidade do funk ostentação em São Paulo. Após a sondagem em documentários e entrevistas com o diretor de cinema Renato Barreiros, ex-subprefeito da Cidade Tiradentes e organizador do primeiro festival de funk de São Paulo (2008), consideramos que o funk ostentação, mais do que uma crise estética ou uma alternativa de consumo, é um acontecimento da própria dinâmica do Funk, que criam o recriam as relações ente bailes de periferia, produção de videoclipes e compartilhamento na Internet. Mc Bin Laden, um importante nome desse movimento, diz que dentro do funk ocorreu uma "atualizada", isto é "a galera esqueceu de ostentar cordão de ouro na favela, carrão, várias minas, voltou para a realidade: o Funk é imprevisto. Ao fazer o gesto de pouso, isto é, focar a atenção no nosso objeto que são as personagens mulheres que estão dentro funk, tentamos compreender os lugares ocupados por elas no território do funk, mesmo considerando que este é um território em constante mudança. Levantamos os primeiros sucessos do funk lançados no site de vídeos YouTube (do funk ou do funk ostentação) em São Paulo e foi notado que as primeiras letras dos MC's ficaram famosas por gozarem do gênero feminino.
Consideramos, então como recorte, os videoclipes da produtora KondZilla, A partir deste material foi possível criar três lugares para as mulheres no funk ostentação: o lugar de MC's nos videoclipes em que as mulheres cantam, o ,lugar de convidada nos Videoclipes em que as mulheres tem participação especial, mas não cantam; o lugar de ostentação nos videoclipes em que as mulheres estão o principal objeto ostentado pelos MC's. Após isso discutiremos a construção do erótico/obsceno nas personagens mulheres dentro dos videoclipes de KondZilla.

\section{Conclusão}

Para Gomes (2011) há contradições e ambiguidades no funk estas ocorrem em todos os recortes que possamos fazer do funk ostentação. Nossa hipótese é de que os lugares ocupados pelas funkeiras, mesmo considerados contraditórios por alguns setores do feminismo, estão em constante modificações, permitindo que as contradições e ambiguidades possam ser apontadas e, principalmente, expostas. No funk ostentação o conceito de status está vinculado a posses, ao lugar ocupado nas narrativas e aos sentimentos de inveja a admiração que provocam. As funkeiras abalam o conceito de status do funk, mas adquirem status quando o lugar ocupam é o de maior protagonismo dentro na música

\section{Agradecimentos}

Meus sinceros agradecimentos a Maria lone, Altair Batista, Renato Barreiros, Carlos Miranda, ao Serviço de Apoio aos Estudantes - SAE e ao CNPq- Conselho Nacional de Desenvolvimento Científico e Tecnológico.

BARROS, L. P. e KASTRUP, V. Cartografar é acompanhar processos. IN: PASSOS, E; 15 KASTRUP, V. (org.), Porto Alegre: Sulina, 2009, GOMES, Mariana. MY PUSSY É O PODER: Representação feminina através do funk: identidade, feminismo e indústria cultural.. 2015. 181 f. Dissertação (Mestrado) - Curso de Programa de Pós em Cultura e Territórialidades, Universidade Federal Fluminense, Niterói, 2015.

ABREU, Nuno Cesar. O Olhar pornô: A representação do obsceno no cinema e no vídeo. Campinas: Mercado das Letras, 1996. HERSCHMANN, Micael. O funk e o hip-hop invadem a cena 2a ed Rio de Janeiro: UFRJ, 2005. 